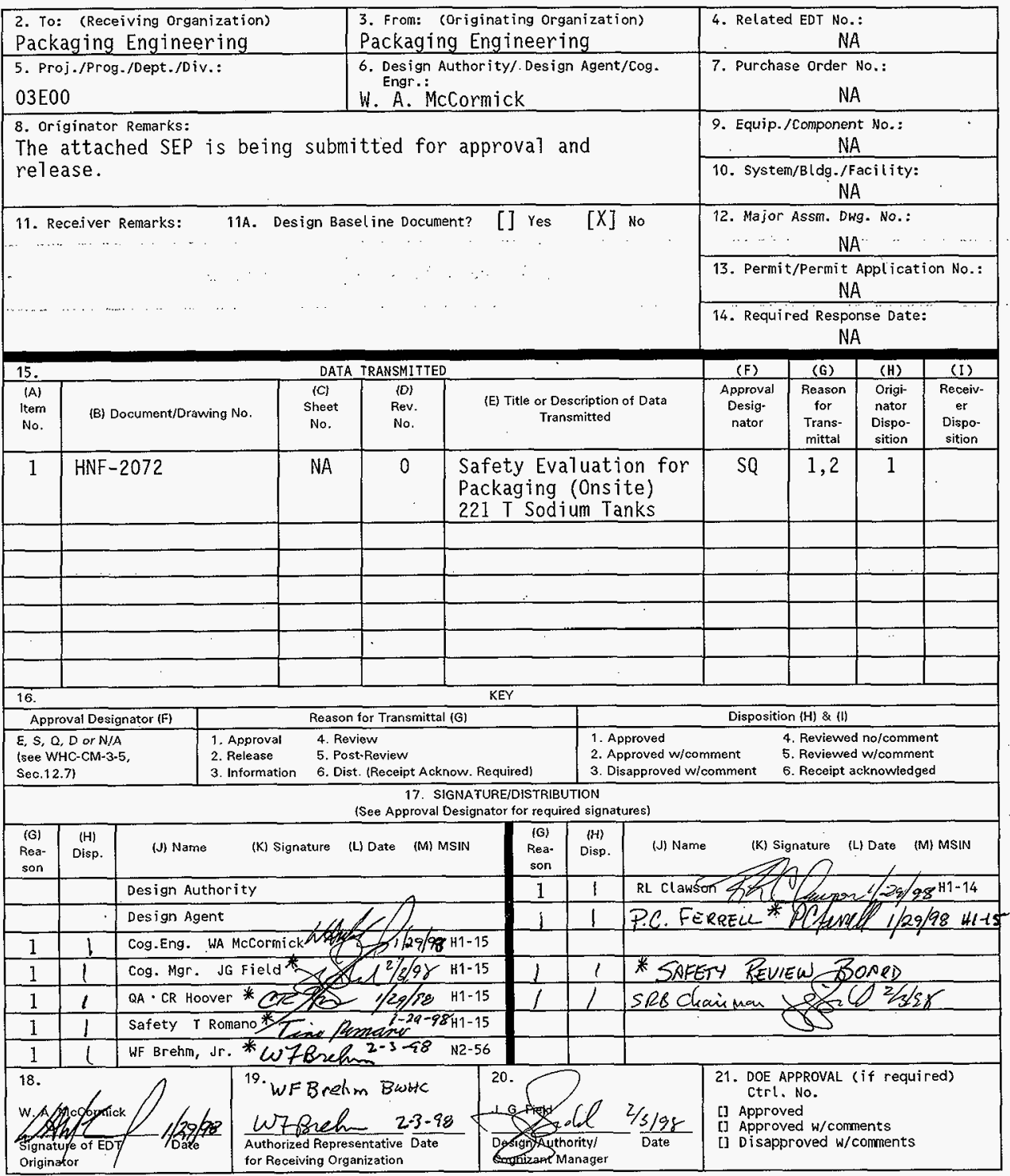




\title{
Safety Evaluation for Packaging (Onsite) 221 T Sodium Tanks
}

\author{
W. A. McCormick
}

Waste Management Federal Services, Inc., Northwest Operations,

Richland, WA 99352

U.S. Department of Energy Contract DE-AC06-96RL13200

EDT/ECN: EDT 621883

Org Code: 03E00

B\&R Code: EX7050000

UC: 513

Charge Code: B1227

Total Pages: 39

Key Words: solid sodium, 337 Building, 200 W Area, 300 Area

Abstract: This safety evaluation for packaging (SEP) allows the transport of approximately $820 \mathrm{~kg}(1800 \mathrm{lb})$ of solid sodium between the $200 \mathrm{~W}$ Area and the 337 Building in the 300 Area of Hanford to be processed for disposal. This SEP authorizes a one-time shipment.

TRADEMARK DISCLAIMER. Reference herein to any specific commercial product, process, or service by trade name, trademark, manufacturer, or otherwise, does not necessarily constitute or imply its endorsement, recommendation, or favoring by the United States Government or any agency thereof or its contractors or subcontractors.

Printed in the United States of America. To obtain copies of this document, contact: WHC/BCS Document Control Services, P.O. Box 1970, Mailstop H6-08, Richland WA 99352, Phone (509) 372-2420; Fax (509) 376-4989.
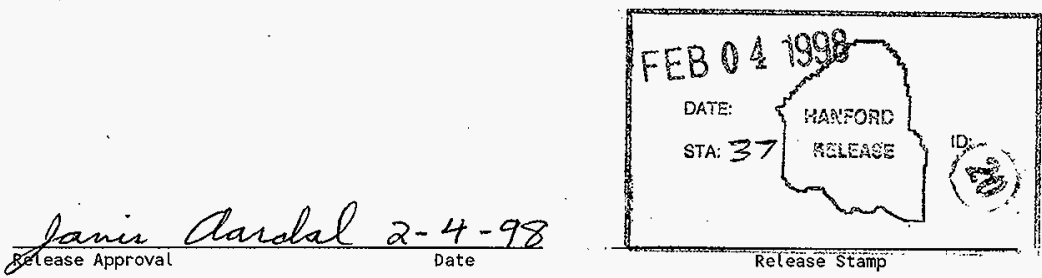
HNF-2072, Rev. 0

CONTENTS

PART A: DESCRIPTION AND OPERATIONS

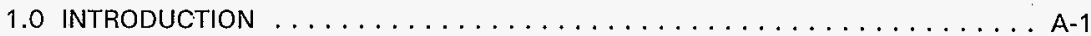

1.1 GENERAL INFORMATION $\ldots \ldots \ldots \ldots \ldots \ldots \ldots \ldots \ldots \ldots \ldots$ A-1

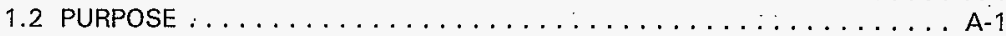

1.3 REVIEW AND UPDATE CYCLES $\ldots \ldots \ldots \ldots \ldots \ldots \ldots \ldots \ldots$ A-1

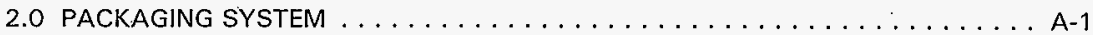

2.1 SMALL TANK (TK-2) $\ldots \ldots \ldots \ldots \ldots \ldots \ldots \ldots \ldots \ldots \ldots \ldots \ldots$ A-1

2.2 LARGE TANK (TK-3) $\ldots \ldots \ldots \ldots \ldots \ldots \ldots \ldots \ldots \ldots \ldots \ldots$ A-2

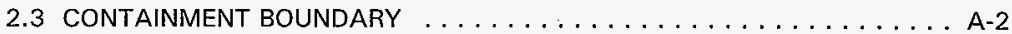

2.4 CAVITY SIZE, PAYLOAD CAPACITY AND GROSS WEIGHT . . . . . . . . A-2

2.5 HEAT DISSIPATION . . . . . . . . . . . . . . . . . . A-3

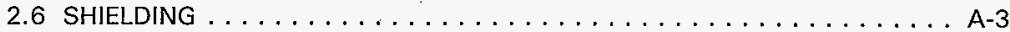

2.7 LIFTING DEVICES $\ldots \ldots \ldots \ldots \ldots \ldots \ldots \ldots \ldots \ldots \ldots \ldots \ldots \ldots \ldots \ldots$

2.8 TIEDOWN DEVICES $\ldots \ldots \ldots \ldots \ldots \ldots \ldots \ldots \ldots \ldots \ldots \ldots \ldots \ldots \ldots \ldots$

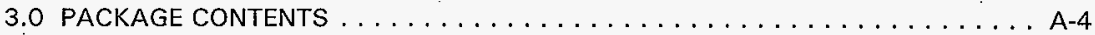

3.1 GENERAL DESCRIPTION $\ldots \ldots \ldots \ldots \ldots \ldots \ldots \ldots \ldots \ldots \ldots$ A-4

3.2 CONTENT RESTRICTIONS $\ldots \ldots \ldots \ldots \ldots \ldots \ldots \ldots \ldots \ldots \ldots$ A-4

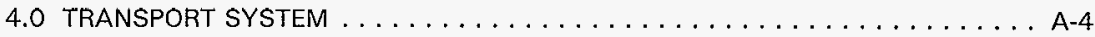

4.1 TRANSPORTER $\ldots \ldots \ldots \ldots \ldots \ldots \ldots \ldots \ldots \ldots \ldots \ldots \ldots \ldots \ldots \ldots \ldots$

4.2 TIEDOWN SYSTEM $\ldots \ldots \ldots \ldots \ldots \ldots \ldots \ldots \ldots \ldots \ldots \ldots \ldots \ldots \ldots \ldots \ldots$

4.3 SPECIAL TRANSFER REQUIREMENTS $\ldots \ldots \ldots \ldots \ldots \ldots \ldots$ A-4

5.0 ACCEPTANCE OF PACKAGING FOR USE $\ldots \ldots \ldots \ldots \ldots \ldots \ldots \ldots$ A-5

6.0 OPERATING REQUIREMENTS $\ldots \ldots \ldots \ldots \ldots \ldots \ldots \ldots \ldots \ldots \ldots \ldots \ldots \ldots \ldots$

7.0 QUALITY ASSURANCE REQUIREMENTS $\ldots \ldots \ldots \ldots \ldots \ldots \ldots \ldots$ A-6

7.1 GENERAL REQUIREMENTS $\ldots \ldots \ldots \ldots \ldots \ldots \ldots \ldots \ldots \ldots \ldots$ A-6

7.2 QUALITY REQUIREMENTS $\therefore \ldots \ldots \ldots \ldots \ldots \ldots \ldots \ldots \ldots$ A-6

7.2.1 Organization $\ldots \ldots \ldots \ldots \ldots \ldots \ldots \ldots \ldots \ldots \ldots \ldots \ldots \ldots \ldots \ldots$

7.3 SEP CONTROL SYSTEM $\ldots \ldots \ldots \ldots \ldots \ldots \ldots \ldots \ldots \ldots \ldots$ A-6

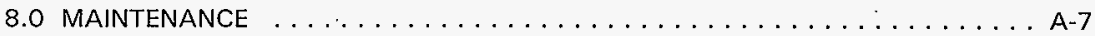

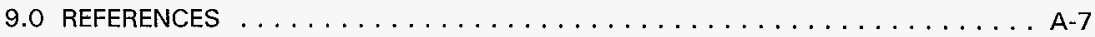


HNF-2072, Rev. 0

CONTENTS (cont)

\section{PART B: PACKAGE EVALUATION}

1.0 INTRODUCTION ........................... B-1

1.1 SAFETY EVALUATION METHODOLOGY $\ldots \ldots \ldots \ldots \ldots \ldots \ldots$ B-1

1.2 EVALUATION SUMMARY AND CONCLUSIONS $\ldots \ldots \ldots \ldots \ldots \ldots$ B-1

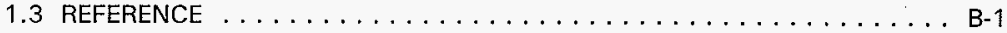

2.0 CONTENTS EVALUATION $\ldots \ldots \ldots \ldots \ldots \ldots \ldots \ldots \ldots \ldots \ldots \ldots \ldots$ B-2

2.1 CHARACTERIZATION $\ldots \ldots \ldots \ldots \ldots \ldots \ldots \ldots \ldots \ldots \ldots$ B-2

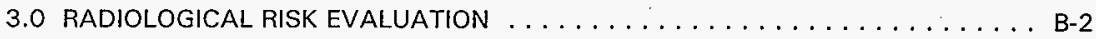

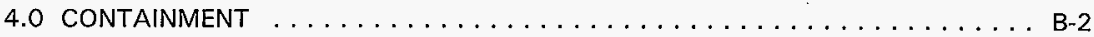

4.1 INTRODUCTION $\ldots \ldots \ldots \ldots \ldots \ldots \ldots \ldots \ldots \ldots \ldots \ldots$ B-2

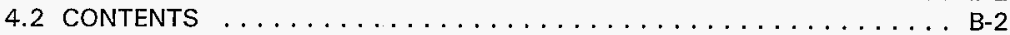

4.3 NORMAL TRANSFER CONDITIONS $\ldots \ldots \ldots \ldots \ldots \ldots \ldots \ldots \ldots$ B-3

4.4 CONTAINMENT EVALUATION $\ldots \ldots \ldots \ldots \ldots \ldots \ldots \ldots \ldots \ldots$ B-3

4.4.1 Containment Requirements ................. B-3

4.4 .2 Evaluation Summary ................ B

4.4.3 Regulatory Requirements . . . . . . . . . . . . . B-4

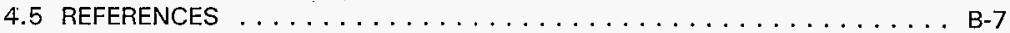

4.6 APPENDIX: CALCULATIONS $; \ldots \ldots \ldots \ldots \ldots \ldots \ldots \ldots \ldots$ B-8

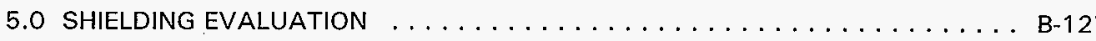

6.0 CRITICALITY EVALUATION $\ldots \ldots \ldots \ldots \ldots \ldots \ldots \ldots \ldots \ldots \ldots \ldots$ B-12

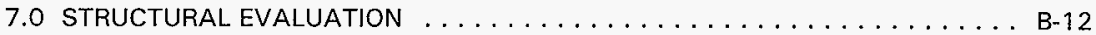

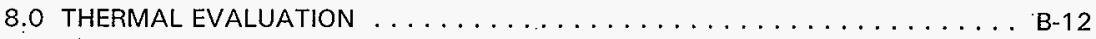

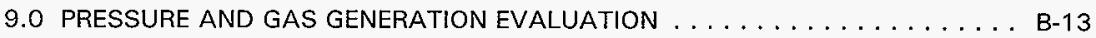

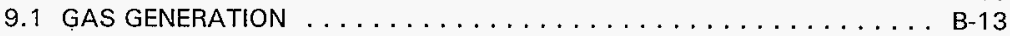

9.2 PACKAGE PRESSURE $\ldots \ldots \ldots \ldots \ldots \ldots \ldots \ldots \ldots \ldots \ldots \ldots \ldots$

10.0 PACKAGE TIEDOWN SYSTEM EVALUATION $\ldots \ldots \ldots \ldots \ldots \ldots \ldots \ldots$ B-13

10.1 SYSTEM EVALUATION $\ldots \ldots \ldots \ldots \ldots \ldots \ldots \ldots \ldots \ldots \ldots$ B-13

10.2 ATTACHMENTS AND RATINGS $\ldots \ldots \ldots \ldots \ldots \ldots \ldots \ldots \ldots$ B-14

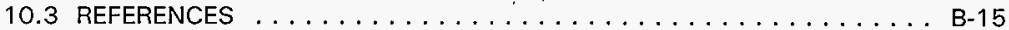

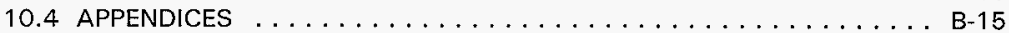

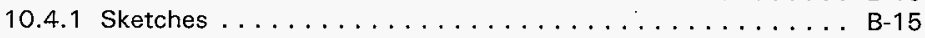

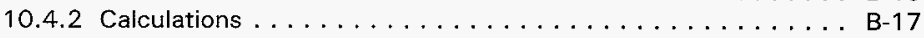


HNF-2072, Rev. 0

\section{LIST OF TABLES}

A2-1 Tank Characteristics $\ldots \ldots \ldots \ldots \ldots \ldots \ldots \ldots \ldots \ldots \ldots \ldots$ A-3

A4-1 External Container Contamination Limits . . . . . . . . . . . A-5

A7-1 Records Retention and Location $\ldots \ldots \ldots \ldots \ldots \ldots \ldots \ldots \ldots$ A-8

B10-1 Tiedown System Design Data $\ldots \ldots \ldots \ldots \ldots \ldots \ldots \ldots \ldots \ldots \ldots \ldots \ldots$ B-14 
HNF-2072, Rev. 0

\section{LIST OF TERMS}

$\begin{array}{ll}\text { ASME } & \text { American Society of Mechanical Engineers } \\ \mathrm{cm} & \text { centimeter } \\ \mathrm{DOT} & \text { U.S. Department of Transportation } \\ \mathrm{gal} & \text { gallon } \\ \mathrm{Hz} & \text { hertz } \\ \mathrm{in} & \text { inch } \\ \mathrm{kg} & \text { kilogram } \\ \mathrm{km} & \text { kilometer } \\ \mathrm{km} / \mathrm{h} & \text { kilometers per hour } \\ \mathrm{kPa} & \text { kilopascal } \\ \mathrm{L} & \text { liter } \\ \mathrm{Ib} & \text { pound } \\ \mathrm{m} & \text { meter } \\ \mathrm{mi} & \text { mile } \\ \mathrm{mi} / \mathrm{h} & \text { miles per hour } \\ \mathrm{MPa} & \text { megapascal } \\ \text { psi } & \text { pounds per square inch } \\ \text { psig } & \text { pounds per square inch (gage) } \\ \mathrm{SEP} & \text { safety evaluation for packaging } \\ \mathrm{WMNW} & \text { Waste Management Federal Services, Inc., Northwest Operations } \\ & \end{array}$


HNF-2072, Rev. 0

\section{SAFETY EVALUATION FOR PACKAGING (ONSITE) 221 T SODIUM TANKS}

\section{PART A: DESCRIPTION AND OPERATIONS}

\subsection{INTRODUCTION}

\subsection{GENERAL INFORMATION}

Approximately $820 \mathrm{~kg}$ ( $1800 \mathrm{lb})$ of solid sodium is being transported between the $200 \mathrm{~W}$ Area and the 337 Building in the 300 Area of Hanford to be processed for disposal. The sodium is currently contained in two tanks, TK-2 and TK-3, in the $221 \mathrm{~T}$ Building. The tanks do not meet the U.S. Department of Transportation requirements for shipping sodium, which is classified as a hazardous material.

\subsection{PURPOSE}

The purpose of this safety evaluation for packaging (SEP) is to demonstrate that the containment properties of tanks TK-2 and TK-3 meet the intent of the hazardous materials shipping regulations and will allow safe transportation of their contents on the Hanford Site. Per the evaluations and conclusions in Part B of this SEP and the operations controls prescribed in Part A of this SEP, the onsite shipping of these tanks and their contents is demonstrated to be acceptable.

\subsection{REVIEW AND UPDATE CYCLES}

This SEP authorizes the one-time shipment of the identified payload. After completion of the shipment, the SEP will become void. No further reviews or updates will be required.

\subsection{PACKAGING SYSTEM}

\subsection{SMALL TANK (TK-2)}

The 114-L (30.0-gal) tank has an outside diameter of $45.72 \mathrm{~cm}(18.0 \mathrm{in}$.$) and is$ $91.4 \mathrm{~cm}$ (36.0 in.) in length. The cylindrical wall is constructed from standard-weight stainless steel pipe. The ends are stainless steel standard-weight pipe heads. The tank is designed to operate at a temperature of $648.9^{\circ} \mathrm{C}\left(1200^{\circ} \mathrm{F}\right)$ and a pressure of $861.8 \mathrm{kPa}$ 
HNF-2072, Rev. O

(125 psi). It has a test pressure of $1103.2 \mathrm{kPa}$ (160 psi). When used, the tank was supported from three equally spaced support lugs fastened to the top head. The top head is penetrated in two places by 0.5 -in. schedule $40 S$ pipe. The pipes do not extend into the tank. The pipes extend just far enough from the tarik outer surface to attach a clamp-on pipe cap for transportation.

The side wall of the tank is penetrated by a 2.0 -in. schedule $40 \mathrm{~S}$ pipe. The pipe extends to the center of the tank and is bent downward. The downward portion of the pipe is $60.3 \mathrm{~cm}$ (23.75 in.) measured from the bottom to the centerline of the wall penetration. The pipe extends just far enough from the tank outer surface to attach a clamp-on pipe cap for transportation.

A packaging designed to hold $113.56 \mathrm{~L}(30.0 \mathrm{gal})$ of sodium for transportation would be classified as a nonbulk packaging and would be required to meet Packing Group I performance requirements. The regulations permit the use of numerous types of single packagings, such as drums and boxes. Tanks are not included in the approved packagings. Tanks, however, are approved for use with larger loads.

\subsection{LARGE TANK (TK-3)}

The 1890-L (500-gal) tank has an outside diameter of $91.4 \mathrm{~cm}$ (36.0 in.) and is $298.5 \mathrm{~cm}$ (117.5 in.) in length. The cylindrical wall is constructed from. standard-weight stainless steel pipe. The ends are stainless steel standard-weight pipe heads. The tank is designed to operate at a temperature of $648.9^{\circ} \mathrm{C}\left(1200^{\circ} \mathrm{F}\right)$ and a pressure of $861.8 \mathrm{kPa}$ (125 psi). It has a test pressure of $1103.2 \mathrm{kPa}$ (160 psi). When used, the tank was supported from three equally spaced support lugs fastened to the top head. The top head is penetrated in two places by 0.5 -in. schedule $40 \mathrm{~S}$ pipes. The pipes do not extend into the tank.

The side wall of the tank is penetrated by a 0.5 -in. schedule 405 pipe. The pipe extends to the center of the tank and is bent downward. The downward portion of the pipe is $60.3 \mathrm{~cm}(23.75 \mathrm{in}$.) measured from the bottom to the centerline of the wall penetration. The pipe extends just far enough from the tank outer surface to attach a clamp-on pipe cap for transportation.

\subsection{CONTAINMENT BOUNDARY}

The containment boundary for both tanks are the containers themselves and the caps on the pipe penetrations.

\subsection{CAVITY SIZE, PAYLOAD CAPACITY AND GROSS WEIGHT}

TK-2 has a volume of $114 \mathrm{~L}$ ( $30.0 \mathrm{gal})$, a sodium capacity of $75.7 \mathrm{~L}$ (20.0 gal), and a gross weight of $209.5 \mathrm{~kg}$ (462 lb) maximum. TK-3 has a volume of $1890 \mathrm{~L}$ (500 gal), a sodium capacity of $1136 \mathrm{~L}$ (300 gal), and a gross weight of $1989 \mathrm{~kg}$ (4385 lb) maximum. Table A2-1 shows the general characteristics for each tank. 
HNF-2072, Rev. O

Table A2-1. Tank Characteristics.

\begin{tabular}{|c|c|c|}
\hline Item & Tank TK-2 & Tank TK-3 \\
\hline Drawing & H-2-38805 (WHC 1976) & H-2-38804 (WHC 1977) \\
\hline $\begin{array}{l}\text { Sodium capacity } \\
\text { (at design fill height) }\end{array}$ & $75.7 \mathrm{~L}(20 \mathrm{gal})$ & $1736 \mathrm{~L}(300 \mathrm{gal})$ \\
\hline Outside diameter (pipe size) & $45.7 \mathrm{~cm}(18 \mathrm{in})$. & $91.4 \mathrm{~cm}(36$ in.) \\
\hline Tank length, head to head & $91.4 \mathrm{~cm}(36$ in. $)$ & $298.5 \mathrm{~cm}$ (117.5 in.) \\
\hline $\begin{array}{l}\text { Pipe wall thickness } \\
\text { (std weight for pipe size) }\end{array}$ & $0.95 \mathrm{~cm}(0.375 \mathrm{in.})$ & $1.27 \mathrm{~cm}(0.5 \mathrm{in})$. \\
\hline Empty weight & $140.6 \mathrm{~kg}(310 \mathrm{lb})$ & $954.8 \mathrm{~kg}(2105 \mathrm{lb})$ \\
\hline Filled weight & $209.5 \mathrm{~kg}(462 \mathrm{lb})$ & $1989 \mathrm{~kg}(4385 \mathrm{lb})$ \\
\hline Maximum weight of contents & $69.0 \mathrm{~kg}(152 \mathrm{lb})$ & $1034.2 \mathrm{~kg}(2280 \mathrm{lb})$ \\
\hline Design fill height & $52.7 \mathrm{~cm}(20.75 \mathrm{in.})$ & $186.7 \mathrm{~cm} \mathrm{(73.5} \mathrm{in.)}$ \\
\hline Center of gravity, empty & At geometric center & At geometric center \\
\hline Center of gravity, full & $\begin{array}{l}5.1 \mathrm{~cm}(2.0 \mathrm{in} .) \text { below } \\
\text { geometric center per } \\
\text { drawing }\end{array}$ & $\begin{array}{l}5.1 \mathrm{~cm}(2.0 \text { in.) below } \\
\text { geometric center per } \\
\text { calculations }\end{array}$ \\
\hline Contents & \multicolumn{2}{|c|}{$\begin{array}{l}\text { Unknown--assume filled (per telecon with Neal Hara, } \\
10 / 8 / 97 \text {, both tanks together contain } 816.5 \mathrm{~kg}[1800 \mathrm{lb}] \\
\text { of sodium) }\end{array}$} \\
\hline
\end{tabular}

WHC, 1977, Sodium Pool Supply Tank Assembly and Details $T K-3$, drawing H-2-38805,

Rev. 1, Westinghouse Hanford Company, Richland, Washington.

WHC, 1976, Sodium Spray Supply Tank Assembly and Detalls TK-2, drawing H-2-38804,

Rev. 1, Westinghouse Hanford Company, Richland, Washington.

\subsection{HEAT DISSIPATION}

Heat dissipation is achieved through passive thermal conduction and radiation. There are no artificial cooling mechanisms employed to dissipate heat, nor are any required.

\subsection{SHIELDING}

No shielding is provided or required for either tank.

\subsection{LIFTING DEVICES}

There are three lifting lugs welded on one end of each tank. 
HNF-2072, Rev. O

\subsection{TIEDOWN DEVICES}

The are no tiedown devices integral to either tank.

\subsection{PACKAGE CONTENTS}

\subsection{GENERAL DESCRIPTION}

Each tank contains essentially pure sodium metal.

\subsection{CONTENT RESTRICTIONS}

The contents are restricted to the amount of sodium metal that is currently in the tanks with the addition of an inert cover gas.

\subsection{TRANSPORT SYSTEM}

\section{1 TRANSPORTER}

The transporter shall consist of a flatbed, lowboy, or van tractor-trailer.

\subsection{TIEDOWN SYSTEN}

The tiedown system shall meet the requirements of the $49 \mathrm{CFR} 393$, "Parts and Accessories Necessary for Safe Operation," Subpart I. An engineered tiedown system shall be used as described and analyzed in Part B, Section 10.0 of this SEP.

\subsection{SPECIAL TRANSFER REQUIREMENTS}

A road closure south of the Wye Barricade is required for this shipment.

Permissible external contamination limits for the tanks are shown in Table A4-1. 
HNF-2072, Rev. 0

Table A4-1. External Container Contamination Limits.

\begin{tabular}{|l|c|c|c|}
\hline \multirow{2}{*}{ Contaminant } & \multicolumn{3}{c|}{ Maximum permissible limits } \\
\cline { 2 - 4 } & $\mathrm{Bq} / \mathrm{cm}^{2}$ & $\mu \mathrm{Ci} / \mathrm{cm}^{2}$ & $\mathrm{dpm} / \mathrm{cm}^{2}$ \\
\hline Beta and gamma emitters and Jow toxicity alpha emitters & 0.4 & $10^{-5}$ & 22 \\
\hline All other alpha-emitting radionuclides & 0.04 & $10^{-6}$ & 2.2 \\
\hline
\end{tabular}

Source: 49 CFR 173, 1997, "Shippers--General Requirements for Shipments and Packagings,

Section .443, "Contamination control.," Code of Federal Regulations, as amended.

\subsection{ACCEPTANCE OF PACKAGING FOR USE}

Prior to shipment, the shipper shall inspect the tanks and transport system to verify the following:

- That all penetrations in the tanks are capped and sealed

- That the external contamination limits are not exceeded

- That the tiedown system is in place as described in Part B, Section 10.0.

\subsection{OPERATING REQUIREMENTS}

The following requirements, as a minimum, shall be completed prior to or during transport, as applicable.

- $\quad$ Prior to shipment, a road closure south of the Wye Barricade shall be arranged.

- The tanks shall be properly marked and labeled.

- The shipping papers shall be completed.

- The transporters shall be properly placarded.

- The tiedown system shall be in place as described in Part B, Section 10.0. 
HNF-2072, Rev. O

\subsection{QUALITY ASSURANCE REQUIREMENTS}

\subsection{GENERAL REQUIREMENTS}

These requirements apply to activities that could affect the quality of the components of the packaging. All operations and documentation shall be in accordance with HNF-PRO-154, Responsibilities and Procedures for All Hazardous Material Shipments,

\subsection{QUALITY REQUIREMENTS}

Appropriate quality assurance requirements shall be imposed by the responsible organization(s) to ensure adequate control relative to maintenance and use of the sodium tanks. All activities, documents, and procedures shall be performed or prepared in accordance with HNF-MP-599, Project Hanford Quality Assurance Program Description (FDH 1997).

\subsubsection{Organization}

Organizational structure and assignment of responsibility shall be such that quality is achieved and maintained by those responsible for performing the work and quality achievement is verified by personnel or organizations not directly responsible for performing the work.

Loading facility operations, Radiological Protection, and receiving facility management are responsible for the quality of work performed by their respective organizations as well as the following:

- Compliance with the current requirements of this SEP

- Providing adequate instructions for implementation of established quality assurance requirements.

The cognizant Quality Assurance organization(s) are responsible for establishing and administering the applicable portions of the Hanford Site quality assurance program relative to the sodium tanks.

\subsection{SEP CONTROL SYSTEM}

This SEP is a controlled supporting document. Only up-to-date approved versions shall be used relative to transport. Changes to this SEP shall be accomplished by Waste Management Federal Services, Inc., Northwest Operations (WMNW) and shall be incorporated and supplied to users via copy controlled distribution.

Review Comment Records produced during initial release or subsequent changes shall be retained as Lifetime Quality Records by WMNW. 
HNF-2072, Rev. O

Table A7-1 shows the records retention periods and location of records.

Table A7-1. Records Retention and Location.

\begin{tabular}{|l|l|l|}
\hline \multicolumn{1}{|c|}{ Document } & Retention period & \multicolumn{1}{c|}{ Location } \\
\hline Safety evaluation for packaging & Lifetime & $\begin{array}{l}\text { WMNW Engineering Business Unit/Information } \\
\text { Resource Management }\end{array}$ \\
\hline Radiation surveys & 5 Years & User facility \\
\hline Operating procedures & 5 Years & User facility \\
\hline Quality assurance audits & Lifetime & User facility \\
\hline Review Comment Records & Lifetime & WMNW Engineering Business Unit \\
\hline Quality Control Inspection Reports & Lifetime & User facility \\
\hline
\end{tabular}

WMNW $=$ Waste Management Federal Services, Inc., Northwest Operations.

\subsection{MAINTENANCE}

The sodium tanks will be shipped only once. Refer to Part A, Section 5.0, and Part A, Section 6.0, for inspection requirements prior to use.

\subsection{REFERENCES}

49 CFR 173, "Shippers--General Requirements for Shipments and Packagings," Code of Federal Regulations, as amended.

49 CFR 393, "Parts and Accessories Necessary for Safe Operation," Code of Federal Regulations, as amended.

FDH, 1997, Project Hanford Quality Assurance Program Description, HNF-MP-599, Rev. 1, Fluor Daniel Hanford, Inc., Richland, Washington.

HNF-PRO-154, Responsibilities and Procedures for All Hazardous Material Shipments, Fluor Daniel Hanford, Inc., Richland, Washington. 
HNF-2072, Rev. O

This page intentionally left blank.

A-8 
HNF-2072, Rev. 0

\section{PART B: PACKAGE EVALUATION}

\subsection{INTRODUCTION}

Part B of this safety evaluation for packaging (SEP) contains evaluations necessary to show that the sodium tanks (TK-2 and TK-3) can be safely transported to the 300 Area from the $200 \mathrm{~W}$ Area.

Review of the material present in the tanks, the physical form of the material, and the present condition of the tanks indicates that a one-time shipment is a reasonable and safe activity using the operational controls established in Part A of this SEP.

\subsection{SAFETY EVALUATION METHODOLOGY}

The safety evaluation methodology for the sodium tanks consists of discussions and analyses demonstrating the ability of the containers to maintain containment equivalent to that required in 49 CFR 173, "Shippers--General Requirements for Shipments and Packagings," for transport of sodium metal.

\subsection{EVALUATION SUMMARY AND CONCLUSIONS}

Based on the evaluations in Part B of this SEP, the one-time transport of the sodium metal in the existing containers is acceptable. The following itemized restrictions apply to this shipment.

- A road closure for south of the Wye Barricade restricting access to unauthorized personal shall be imposed.

- The tanks shall be tied down to the transport vehicle in accordance with the engineered tiedown system described in Part B, Section 10.0, of this SEP.

\subsection{REFERENCE}

49 CFR 173, "Shippers--General Requirements for Shipments and Packagings," Code of Federal Regulations, as amended. 
HNF-2072, Rev. 0

\subsection{CONTENTS EVALUATION}

\subsection{CHARACTERIZATION}

Each tank contains essentially pure sodium metal. The contents are restricted to the amount of sodium metal that is currently in the tanks with the addition of an inert cover gas (nitrogen).

\subsection{RADIOLOGICAL RISK EVALUATION}

Because there are no radioactive constituents included in the waste matrix, this section is not required.

\subsection{CONTAINMENT}

\subsection{INTRODUCTION}

Approximately $820 \mathrm{~kg}(1800 \mathrm{lb})$ of solid sodium is being transported between the $200 \mathrm{~W}$ Area and the 337 Building in the 300 Area of Hanford to be processed for disposal. The sodium is currently contained in two tanks, TK-2 and TK-3, in the 221. T Building. TK-2 has a volume of $114 \mathrm{~L}$ (30 gal), a sodium capacity of $75.7 \mathrm{~L}$ (20 gal), and a gross weight of $230 \mathrm{~kg}(500 \mathrm{lb})$. TK-3 has a volume of $1890 \mathrm{~L}$ (500 gal), a sodium capacity of $1136 \mathrm{~L}$ (300 gal), and a gross weight of $2270 \mathrm{~kg}(5000 \mathrm{lb})$.

The tanks do not meet the U.S. Department of Transportation (DOT) requirements for shipping sodium, which is classified as a hazardous material. This evaluation demonstrates that the containment properties of tanks TK-2 and TK- 3 meet the intent of the hazardous materials shipping regulations and will allow safe transportation of their sodium contents on the Hanford Site.

\subsection{CONTENTS}

Sodium is listed in the Hazardous Materials Table and in the Hazardous Substances Other Than Radionuclides table of 49 CFR 172.101, "Purpose and use of hazardous materials table.," Appendix A, "List of Hazardous Substances and Reportable Quantities." The Hazardous Substances table gives its reportable quantity as $4.54 \mathrm{~kg}$.

The Hazardous Materials Table lists it as a Division 4.3 material (dangerous when wet), with identification number UN1428 and Packing Group of I. This evaluation conservatively assumes that both tanks are filled to capacity. 
HNF-2072, Rev. O

\subsection{NORMAL TRANSFER CONDITIONS}

All insulation or other material shall be removed from the tank to allow a visual inspection of the outside of the tank. Any evidence of leakage shall be reported and a repair procedure developed.

The tanks were originally fabricated with projecting 0.5 -in. or 2.0 -in. Schedule 405 pipes for a welded attachment to the vent and sodium piping systems. The pipes shall be cut at the point that they were welded to the piping system, or closer to the tank. This will ensure that the tank code jurisdiction boundaries are preserved. However, there must be sufficient length of pipe left on the tank for a clamp-on cap to be attached.

A gasketed pipe cap shall be clamped onto the projecting pipes with sufficient clamping force to prevent them loosening due to vibration during a $32.2-\mathrm{km}(20-\mathrm{mi})$ shipment. Assuming a speed of $64.4 \mathrm{~km} / \mathrm{h}(40 \mathrm{mi} / \mathrm{h})$, the trip will take 30 minutes or 1800 seconds. Truck trailers produce a vibration in the region of 2 to $5 \mathrm{~Hz}$, so the caps will be subject to about 9000 cycles of low-frequency vibration, which will not affect a properly tightened pipe clamp. The caps shall allow an inert cover gas of nitrogen or argon to be introduced into the tanks with a positive pressure of about $13.8 \mathrm{kPa}(2.0 \mathrm{psi})$ with verification of the pressure. The inert atmosphere and positive pressure inside the tanks are the primary means to ensure that water does not enter the tanks.

The tightness of the caps and the inert gas pressure in the tanks shall be checked immediately after loading the tanks onto the trailer, immediately prior to shipping, and immediately upon arrival to ensure the tank still contains positive pressure and the inert atmosphere is still effective.

The tanks shall be lifted with a three-legged sling with legs $122 \mathrm{~cm}$ (48 in.) long. TK-2 has three braces projecting from its sides, and TK-3 has six braces. These braces shall not be used as attachment points for lifting, and except as allowed in the tiedown section of this SEP, they will not be used to secure the tanks to the trailer.

\subsection{CONTAINMENT EVALUATION}

\subsubsection{Containment Requirements}

The fundamental requirements of 49 CFR 173.24, "General requirements for packagings and packages," for shipping hazardous materials are as follows.

1. There will be no identifiable release of hazardous materials to the environment.

2. The effectiveness of the package will not be substantially reduced; for example, impact resistance, strength, packaging compatibility, etc., must be maintained for the minimum and maximum temperatures encountered during transportation. 
HNF-2072, Rev. 0

3. There will be no mixture of gases or vapors in the package that could, through any credible spontaneous increase of heat or pressure, significantly reduce the effectiveness of the packaging.

\subsubsection{Evaluation Summary}

To ensure that there is no release of material, the containment system must keep the sodium dry to prevent a chemical reaction between water and sodium. To accomplish this, both tanks will be shipped with a dry inert gas under positive pressure inside the tank to prevent water inleakage.

TK-2 and TK-3 meet the intent of the design rules for DOT 51 portable tanks, which are allowed for transporting sodium in commerce. This fact, plus the loading and transportation requirements of this SEP, ensure that the performance of the packaging will not be reduced by normal transfer conditions.

The only gas in the tanks will be the inert cover gas, which will not react with the sodium or the tanks.

The authorized bulk packagings are given in 49 CFR 173.244, "Bulk packaging for certain pyrophoric liquids (Division 4.2), dangerous when wet (Division 4.3) materials, and poisonous liquids with inhalation hazards (Division 6.1)." The non-bulk packaging is given in 49 CFR 173.211, "Non-bulk packagings for solid hazardous materials in Packing Group I." Both are subject to special provisions B9, B48, B68, N34,T15,T29,T46 of 49 CFR 172.102, "Special provisions." (omitting the air transport codes), of the Hazardous Materials Table. Except for rail tank cars and cargo tank motor vehicles, the only authorized bulk packaging is a DOT 51 portable tank, whose requirements are provided in 49 CFR 178.245, "Specification 51; steel portable tanks."

\subsubsection{Regulatory Requirements}

The 49 CFR 178.245 requirements that are relevant to the safety of this shipment are as foliows.

1. The tank is required to be designed, constructed, certified, and stamped in accordance with the American Society of Mechanical Engineers (ASME) and to have a water capacity of $454 \mathrm{~kg}$ (1000 lb or 264 gal).

Neither tank is ASME certified, and their specifications are unknown. However, both were designed to contain sodium and nitrogen under $517 \mathrm{kPa}$ (75 psi) or $862 \mathrm{kPa}(125 \mathrm{psi})$ at $648.9^{\circ} \mathrm{C}\left(1200^{\circ} \mathrm{F}\right)$ pressure and have design details that are in accordance with the requirements of ASME Boiler and Pressure Vesse/ Code, Section VIII (ASME 1995). Welds shown on drawings H-2-38805, Sodium Pool Supply Tank Assembly and Details TK-2 (WHC 1976), and H-2-38804, Sodium Spray Supply Tank Assembly and Details TK-2 (WHC 1977), are full-penetration groove welds with specific procedure call-outs. 
TK-2 is smaller than the minimum required size. This is unimportant for a tank that is not in commerce because it will be under control throughout the loading, transportation, and unloading process.

2. All openings must be valved or plugged, and the largest size plugged opening allowed is $7.6 \mathrm{~cm}$ (3.0 in.).

The only openings are $1.27-\mathrm{cm}(0.5-\mathrm{in}$.$) and 5.1-\mathrm{cm}(2.0$-in.) nozzles for process piping. The nozzles are welded to the shell of the tanks with fullpenetration groove welds. Openings will be capped during transport.

3. All material used for the tank must be suitable for use with the material to be transported, and the material thickness must be $0.5 \mathrm{~cm}(3 / 16 \mathrm{in}$.) or greater.

The tanks were in service only for a sodium spray test, which lasted a relatively short time, and have not been operated for over 12 years. High temperature sodium is compatible with stainless steel, with corrosion rates of 2 mils/yr only with high oxygen content and high flow rate (Whitlow et al.1971). At this rate, the wall thickness would be reduced by $0.1 \mathrm{~cm}(0.05 \mathrm{in}$ ); TK-2 has a wall thickness of $1.0 \mathrm{~cm}(0.38 \mathrm{in}$.$) , and TK-3$ has a wall thickness -of $1.27 \mathrm{~cm}(0.5 \mathrm{in.})$, so corrosion will not significantly affect their ability to contain solid sodium.

4. The design pressure is based on the vapor pressure of the material being transported, but is neither less than $689.5 \mathrm{kPa}$ (gage) (100 psig) nor greater than $3.45 \mathrm{MPa}$ (gage) (500 psig).

The only internal pressure sources in TK-2 and TK-3 are the inert cover gas and the vapor pressure of sodium. The total internal pressure will be about $13.8 \mathrm{kPa}$ ( $2 \mathrm{psi}$ ). The calculations in Section 4.6 show that the design pressure at room temperature exceeds $2.0 \mathrm{MPa}$ (290 psi), exceeding the regulatory minimum. The temporary caps will have a pressure rating of about $551.6 \mathrm{kPa}(80 \mathrm{psi})$, based on their use in plumbing systems. Because there is no internal source of pressure, the $689.5-\mathrm{kPa}(100-\mathrm{psi})$ internal pressure design requirement can be viewed as a requirement for a robust tank to resist handling accidents that are not itemized in the 49 CFR 178.245 requirements; therefore, the low pressure ratings of the caps is not of concern.

5. The tank mountings must prevent excessive concentrated loads on the shell of the tank. Lifting lugs must be designed for double the load they carry, with a factor of safety of 4 based on the ultimate strength of the material.

TK-2 and TK-3 were designed for vertical operation and were not intended to be portable tanks. Their mountings are not suitable for transportation, so the specific design rules for skids and mountings are not applicable. Instead, the tiedown systems shall be designed to distribute loads to the tanks in a manner that avoids concentrating loads on the tanks. 
HNF-2072, Rev. O

In service, the tanks were suspended from three lugs welded to their top head. The welds have a calculated factor of safety of 9 against failure when evaluated to the criteria of ASME (1995) Section VIII, Division 1, so are suitable for lifting the tanks also. While the rules for DOT 51 portable tanks require doubler plates for lug attachments, they are not necessary in this instance because the shear stress in tank shell without doublers is very low as demonstrated by the calculations in Section 4.6 .

6. All tank fittings must be protected against mechanical damage.

During loading and transportation, the projecting pipes and lateral arms shall be protected from mechanical loads except those approved in the tiedown section of this SEP.

The requirements of 49 CFR 172.102 of the Hazardous Materials Table are specifically for sodium shipments. The requirements relevant to this shipment are as follows.

1. No bottom outlets are permitted.

The tank has no bottom outlets in either the operating or transport configuration shown in the tiedown section of this SEP:

2. Visual inspection is adequate: no hydrotest is required.

Both tanks will be inspected for evidence of sodium leakage after the insulation is stripped, and both will retain pressure prior to shipping.

3. The tank is loaded with molten sodium with an outage of $5 \%$ or more at $98^{\circ} \mathrm{C}$.

TK-2 has a 113.6-L (30.0-gal) capacity and a maximum fill level of $75.7 \mathrm{~L}$ (20.0 gal), so has an outage of about $33 \%$. TK-3 has a capacity of $1893 \mathrm{~L}$ (500 gal), a fill level of $1135.6 \mathrm{~L}(300 \mathrm{gal}$ ), so has an outage of about $40 \%$. Since the tanks were loaded with liquid sodium and allowed to cool, this requirement is met.

4. Aluminum construction materials are not authorized for any part of a packaging that is normally in contact with the hazardous material.

The tanks are constructed entirely of stainless steel.

5. The lading must be covered with nitrogen or other inert gas.

Both tanks are currently connected to the nitrogen system used in the operation of the sodium spray system. After disconnecting the tanks from the system, nitrogen or other inert gas will be used to flood the tanks, displacing as much air as practical. They will then be pressurized with about $13.8 \mathrm{kPa}(2.0 \mathrm{psi})$ prior to transportation. 
HNF-2072, Rev. 0

\subsection{REFERENCES}

49 CFR 172, "Hazardous Materials Table, Special Provisions, Hazardous Materials Communications, Emergency Response Information, and Training Requirements," Code of Federal Regulations, as amended.

49 CFR 173, "Shippers--General Requirements for Shipments and Packagings," Code of Federal Regulations, as amended.

49 CFR 178, "Specifications for Packagings," Code of. Federal Regulations, as amended.

AISC, 1980, Manual of Steel Construction, 8th edition, American Institute of Steel Construction, Chicago Illinois.

ASME, 1995, Boiler and Pressure Vessel Code, Section VIII, Division 1, American Society of Mechanical Engineers, New York, New York.

WHC, 1977, Sodium Pool Supply Tank Assembly and Details TK-3, drawing H-2-38804, Rev. 1, Westinghouse Hanford Company, Richland, Washington.

WHC, 1976, Sodium Spray Supply Tank Assembly and Details TK-2, drawing H-2-38805, Rev. 1, Westinghouse Hanford Company, Richland, Washington.

Whitlow G. A., J.C. Cwynar, R. L. Miller, and S. L. Schrock, 1971, "Sodium Corrosion Behaviour of Alloys for Fast Reactor Applications," Westinghouse Nuclear Energy Systems, Advanced Reactors Division, published in Chemical Aspects of Corrosion and Mass Transfer in Liquid Sodium, Sven A. Jansson ed, The Metallurgical Society of the American Institute of Mining, Metallurgical, and Petroleum Engineers, New York, New York. 


\subsection{APPENDIX: CALCULATIONS}

\section{ENGINEERING SAFETY EVALUATION}

Subject: 49 CFR conformance of Tank TK-2, TK-3
Preparer: W.W. Smyth
Checker: $\quad$ S.S. SHIRIAGA
Section Chief: S.S.SHIRAGA

Page 1 of 4

Date 19 NOV 1997

Date 19 NOV 1997

Date 19 NOV 1997

\subsection{OBJECTIVE}

1. Find the equivalent ASME section VIII design pressure for tanks TK-2 and TK-3.

2. Determine whether the lack of doubler plates under the lifting lugs is acceptable.

2. Find the margin of safety against exceeding the 49 CFR 178.245 requirements for the lifling lugs.

\subsection{REFERENCES}

49 CFR 178.245, 1996, "Specification 51; steel portable tanks.," Code of Federal Regulations, as amended.

AISC, 1980, Manual of Steel Construction, 8th edition, American Institute of Steel Construction, Chicago Illinois, 1980

H 2-38805, WHC drawing, Tank TK-2:

H 2-38804, WHC drawing, Tank TK-3

\subsection{ASSUNRTIONS, RESULTS, AND CONCLUSIONS}

Assume:

1. That both tanks are filled to their design capacity with sodium, and have piping, insulation and heaters removed so they appear as on their reference drawings.

2. The weight for TK-3 is assumed to be $5000 \mathrm{lb}$, which is greater than the weight stated on the drawing to allow for insulation and appurtances. The lugs for both tarks are the same, so the lugs for TK-2 will not be analysed since the tank weighs only $500 \mathrm{lb}$.

3. The lifting arraingement is similar to that show in the sketch.

4. The tank heads are an ASME configuration, with the same thickness as the pipe. The cylindrical portion of the tank will then control the design pressure, and no stess analysis is needed for the head or head-cylinder joint.

Conclusions:

1. Considering only the primary stress in the tank cylinders, TK-2 has a calculated design pressure of 450 psi, and that of TK-2 is 293 psi.Both exceed the design pressure requirement of 49 CFR 425 for DOT 51 portable tanks.

2. No doubler plates are necessary.

3. The lifing lug attachment weld has a factor of safety of 9 against failure, and meets the requirement of 49 CFR 178.245. 
HNF-2072, Rev. 0

\section{ENGINEERING SAFETY EVALUATION}

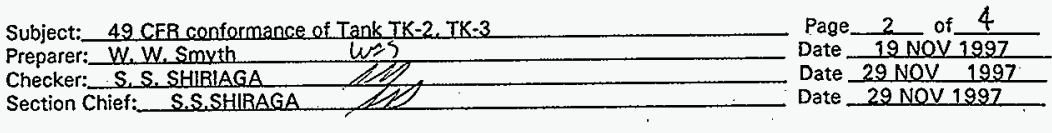

\subsection{EVALUATION}

Calculate a design pressure based on ASME section VIII, division I, subsection UG-27:

Cylinder

$$
\begin{aligned}
& S:=17700 \text { psi } \quad S_{u} \text { for ASME section II, welded pipe, type } 316 \text { steel } \\
& E:=0.6 \quad \text { section UW-12: sssume one-sided weld, no radiography }
\end{aligned}
$$

TK-2: $t:=0.375 \cdot$ in

$$
\begin{array}{ll}
\text { Cylinder } R:=9 \cdot \text { in }-t \quad p:=\frac{S \cdot E-t}{R+.6 \cdot t} \quad p=450 \cdot p s i \\
\text { Ellipsoidal head } \quad D:=2 \cdot R \quad p:=\frac{2 \cdot S \cdot E \cdot t}{D+0.22 \cdot t}, \quad p=460 \cdot p s i
\end{array}
$$

$$
\begin{aligned}
& \text { TK-3: } \quad t:=0.5 \cdot \text { in } \\
& \text { Cylinder } \quad R:=18 \cdot \text { in }-t \quad p:=\frac{S \cdot E \cdot t}{R+.6 \cdot t} \quad p=298 \cdot p s i \\
& \text { Ellipsoidal head } \quad D:=2 \cdot R \quad p:=\frac{2 \cdot S \cdot E \cdot t}{D+0.2 \cdot t} \quad p=303 \cdot p s i
\end{aligned}
$$

Find the stress in the tank sheil near the lugs to determine whether doublers should have been used.

Near from the lugs the tank wall will be in a state of shear due to lifting loads. Find the shear around the weld periphery and compare this to the ASME allowable stress intensity

$$
\begin{aligned}
& \mathrm{L}:=6 \cdot \mathrm{in} \quad \text { Lug length } \\
& W:=1.5 \cdot \text { in Width of lug and } 23 / 8 \text { in fillet welds. } \\
& t:=.5 \cdot \text { in Shell thickness } \\
& P:=5000 \cdot \mathrm{lbf} \text {. Weight of loaded tank, supported from } 3 \text { tugs. } \\
& A_{S}:=2 \cdot(\mathrm{W}+\mathrm{L}) \cdot \mathrm{t} \quad \text { shear area }=\text { thickness * circumference } \\
& \quad \tau:=\frac{\mathrm{P}}{3 \cdot \mathrm{A}_{\mathrm{S}}} \quad \tau=222 \cdot \mathrm{psi} \quad \text { average shear stress through shell }
\end{aligned}
$$

The stress intensity allowed for type 316 welded pipe is $17.7 \mathrm{ksi}$ for temperatures up to $200 \mathrm{deg} F$. With an average shear stress so low, no doubler plate is required to distribute the forces from the lifting lugs due to loading the tank. 
HNF-2072, Rev. 0

\section{ENGINEERING SAFETY EVALUATION}

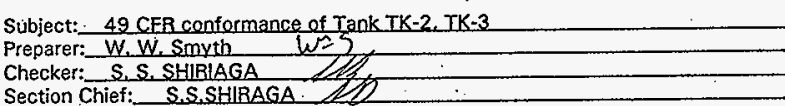

Page _... 3 of 4 Date 19 NOV 1997

Date 19 NOV 1997

Date 19 NOV 1997

Find weld stresses in the support lug \& compare to allowable stress for ASME section VIII vessels. The steel is type 304 stairless steel.

Welds are $3 / 8^{n}$ fillets, and the lug is $3 / 4$ in thick - the weld strength will govem the capacity.

$\mathrm{A}_{\mathrm{w}}:=2 \cdot 6 \cdot \mathrm{in} \cdot 375 \cdot \mathrm{in} \cdot .707$ effective weld area

moment of inertia $=\quad I:=\frac{2}{12} \cdot .25 \cdot \mathrm{in} \cdot .707 \cdot(6 \cdot \mathrm{in})^{3}$.

$\mathrm{A}_{\mathrm{W}}=3.181 \cdot \mathrm{in}^{2} \quad \mathrm{I}=6.363 \cdot \mathrm{in}^{4}$

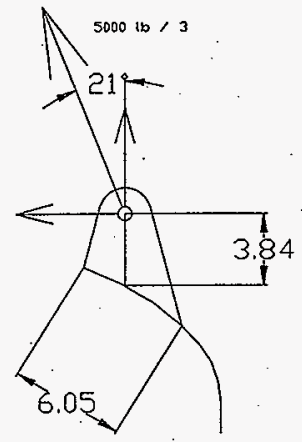

Using the geometry assumed in the sketch, which is based on a 3 -legged sling with each leg $36^{n}$ long, the loads applied to the welds are:

$$
\begin{aligned}
& \text { Tension: } \quad T:=\frac{5000}{3} \cdot \mathrm{lbf} \cdot \cos (21 \cdot \mathrm{deg}) \quad \mathrm{T}=1556 \cdot \mathrm{lbf} \\
& \text { Shear: } \quad \mathrm{V}:=5000 \cdot \frac{\mathrm{lbf}}{3} \cdot \sin (21 \cdot \mathrm{deg}) \quad \mathrm{V}=597 \cdot \mathrm{lbf} \\
& \text { Moment: } \quad \mathrm{M}:=\mathrm{V} \cdot 3.84 \cdot \text { in } \quad \mathrm{M}=2294 \cdot 1 \mathrm{bf} \cdot \text { in } \\
& \sigma_{\mathrm{a}}:=\frac{\mathrm{T}}{\mathrm{A}_{\mathrm{w}}} \quad \sigma_{\mathrm{a}}=489 \cdot \mathrm{psi} \quad \sigma_{\mathrm{v}}:=\frac{\mathrm{V}}{\mathrm{A}_{\mathrm{w}}} \quad \sigma_{\mathrm{v}}=188 \cdot \mathrm{psi} \\
& \sigma_{b}:=\frac{M \cdot\left(\frac{6.05}{2}\right) \cdot \text { in }}{I} \quad \sigma_{b}=1090 \cdot p s i
\end{aligned}
$$


HNF-2072, Rev. O

\section{ENGINEERING SAFETY EVALUATION}

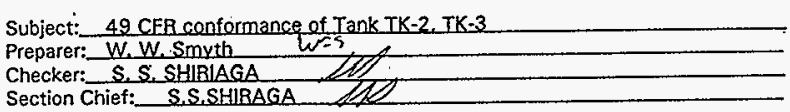

Page 4 of 4 Date 19 NOV 1997 Date 19 NOV 1997 Date 19 NOV 1997

Material properties for type 316 stainless steel (ASME section II, part D):

$$
\begin{aligned}
& F_{\mathbf{u}}:=75000 \cdot \text { psi } \quad F_{y}:=30000 \cdot \text { psi } \quad S_{\mathfrak{u}}:=17700 \cdot p s i \\
& E:=0.55 \quad \text { ASME weld efficiency, div VIr, } U W-18
\end{aligned}
$$

ASME allowable stress : $\quad \dot{F}_{\cdot v}:=E \cdot S_{u} \quad F_{v}=9735 \cdot p s i$

Assuming a factor of safety against yielding of 1.5 for ASME weld design, find the margin to yield:

$$
\frac{F_{v^{-1.5}}}{f_{v}}=9.2
$$

This exceeds the DOT requirement for a factor of safety of 8 . 
HNF-2072, Rev. 0

\subsection{SHIELDING EVALUATION}

Because there are no radioactive constituents included in the waste matrix, this section is not required.

\subsection{CRITICALITY EVALUATION}

Because there are no radioactive constituents included in the waste matrix, this section is not required.

\subsection{STRUCTURAL EVALUATION}

Because the sodium tanks do not specifically meet the DOT requirements for shipping sodium, which is classified as a hazardous material, it is required that the tanks be evaluated for their capability of meeting the intent of the DOT regulations for containment in order to be transported onsite.

The evaluation in Part B, Section 4.0, demonstrates that the containment properties of tanks TK-2 and TK-3 meet the intent of the hazardous materials shipping regulations and will allow safe transportation of their sodium contents on the Hanford Site. No further evaluation is required.

\subsection{THERMAL EVALUATION}

Heat dissipation in the sodium tanks is achieved through passive thermal conduction and radiation. There are no artificial cooling mechanisms employed to dissipate heat, nor are any required. Sodium metal is not a thermal heat source. The containers are filled with an inert cover gas and sealed prior to transport. Reaction due to contact with air or water is not a concern. No further evaluation is required. 
HNF-2072, Rev. 0

\subsection{PRESSURE AND GAS GENERATION EVALUATION}

\subsection{GAS GENERATION}

Hydrogen gas generation due to radiolysis requires the presence of hydrogen atoms in a molecular matrix that releases hydrogen atoms when energized with ionizing radiation. Normally this occurs when the package contains water, organic material, and polyethylene or other plastic material.

The sodium tanks do not contain any radioactive constituents in the waste matrix; therefore, hydrogen gas generation is not a concern.

\subsection{PACKAGE PRESSURE}

Package pressurization can result from radiolytic hydrogen gas generation, thermal heat buildup, and major changes in barometric pressure. As stated previously, hydrogen gas generation is not a concern. Decay heat from the payload is minimal; therefore, thermal heat buildup is not a concern. No major changes in barometric pressure will occur during this shipment; therefore, pressure buildup via this mechanism is also not a concern.

No further evaluation is required.

\subsection{PACKAGE TIEDOWN SYSTEM EVALUATION}

\subsection{SYSTEM EVALUATION}

Two tanks containing solid sodium are to be secured to a flatbed trailer for transportation between the $221 \mathrm{~T}$ Building in the $200 \mathrm{~W}$ Area to the 300 Area. The requirements of 49 CFR 393.102, "Securement systems.," are used as acceptance criteria; the load tiedown must have a working strength greater than one-half of the load weight in any direction.

Both tanks are made from stainless steel pipe with formed heads. Both are operated vertically, suspended by three lugs welded to the top head, and have legs projecting radially from the tanks for lateral support. It was not feasible to use the legs to support the tanks horizontally. Table B10-1 shows the data ușed to design the tiedown system.

The tanks shall be secured as shown in the sketches in Section 10.4.1. The calculations in Section 10.4.2 demonstrate that the tiedown criteria are met by this tiedown system. 
Table B10-1. Tiedown System Design Data.

\begin{tabular}{|c|c|c|}
\hline Item & Tank TK-2 & Tank TK-3 \\
\hline Drawing & $\mathrm{H}-2-38805(\mathrm{WHC} 1976)$ & $\mathrm{H}-2-38804$ (WHC 1977) \\
\hline $\begin{array}{l}\text { Sodium capacity } \\
\text { (at design fill height) }\end{array}$ & $75.7 \mathrm{~L}(20$ gal) & $1136 \mathrm{~L}(300 \mathrm{gal})$ \\
\hline Outside diameter (pipe size) & $45.7 \mathrm{~cm}(18 \mathrm{in.})$ & $91.4 \mathrm{~cm}(36 \mathrm{in.})$ \\
\hline Tank length, head to head & $91.4 \mathrm{~cm}$ (36 in.) & $298.5 \mathrm{~cm}(117.5 \mathrm{in.})$ \\
\hline $\begin{array}{l}\text { Pipe wall thickness } \\
\text { (std weight for pipe size) }\end{array}$ & $0.95 \mathrm{~cm}(0.375 \mathrm{in})$. & $1.27 \mathrm{~cm}(0.5 \mathrm{in.})$ \\
\hline Empty weight & $140.6 \mathrm{~kg}(310 \mathrm{lb})$ & $954.8 \mathrm{~kg}(2105 \mathrm{lb})$ \\
\hline Filled weight & $209.5 \mathrm{~kg}(462 \mathrm{lb})$ & $1989 \mathrm{~kg}(4385 \mathrm{lb})$ \\
\hline Maximum weight of contents & $69.0 \mathrm{~kg}(152 \mathrm{lb})$ & $1034.2 \mathrm{~kg}(2280 \mathrm{lb})$ \\
\hline Design fill height & $52.7 \mathrm{~cm}(20.75 \mathrm{in.})$ & $186.7 \mathrm{~cm}(73.5 \mathrm{in})$. \\
\hline Center of gravity, empty & At geometric center & At geometric center \\
\hline Center of gravity, full & $\begin{array}{l}5.1 \mathrm{~cm}(2.0 \mathrm{in} .) \text { below } \\
\text { geometric center per } \\
\text { drawing }\end{array}$ & $\begin{array}{l}5.1 \mathrm{~cm}(2.0 \text { in. }) \text { below } \\
\text { geometric center per } \\
\text { calculations }\end{array}$ \\
\hline Contents & \multicolumn{2}{|c|}{$\begin{array}{l}\text { Unknown--assume filled (per telecon with Neal Hara, } \\
10 / 8 / 97 \text {, both tanks together contain } 816.5 \mathrm{~kg}[1800 \mathrm{lb}] \\
\text { of sodium) }\end{array}$} \\
\hline
\end{tabular}

WHC, 1977, Sodium Pool Supply Tank Assembly and Details TK-3, drawing H-2-38805, Rev. 1, Westinghouse Hanford Company. Richland, Washington.

WHC, 1976, Sodium Soray Supply Tank Assembly and Details TK-2, drawing H-2-38804,

Rev. 1, Westinghouse Hanford Company, Richland, Washington.

\subsection{ATTACHMENTS AND RATINGS}

The lifting lugs on the top head may be used to lift the tanks, but shall not be used as tiedown attachment points. The three lateral brackets on tank TK-2 and the six on TK-3 shall not be used to support or tie the tanks down, except as shown in the sketches in Section 10.4.1.

Both tanks are secured to a flatbed trailer using a combination of cribbing and straps. The straps shall have a minimum working load limit of $1134 \mathrm{~kg}(2500 \mathrm{lb})$. TK-2 uses two cradles fabricated from lumber and $1.27-\mathrm{cm}(0.5-\mathrm{in}$.$) plywood sheathing. Each$ cradle has two $4 \times 4$ frames that are nailed to the trailer deck to resist lateral loading and two straps to resist vertical and longitudinal loading. This tank is secured to the trailer with its long axis perpendicular to the length of the trailer. The straps provide longitudinal and vertical restraint, while the cradles provide lateral restraint and prevent the tank from rolling. 
HNF-2072, Rev. 0

TK-3 is secured to the trailer with its long axis parallel to the length of the trailer using a pallet and two straps. The pallet is nailed to the trailer deck to provide longitudinal restraint to resist. The pallet has two $4 \times 4$ 's attached to its upper side that prevent the tank from rolling and, working with two straps, provide resistance to longitudinal forces. The straps also resist lateral and vertical forces.

Refer to Section 10.4.2 for the tiedown analysis.

\subsection{REFERENCES}

49 CFR 393, 1996, "Parts and Accessories Necessary for Safe Operation," Code of Federal Regulations, as amended.

WHC, 1977, Sodium Pool Supply Tank Assembly and Details TK-3, drawing H-2-38805, Rev. 1, Westinghouse Hanford Company, Richland, Washington.

WHC, 1976, Sodium Spray Supply Tank Assembly and Details TK-2, drawing H-2-38804, Rev. 1, Westinghouse Hanford Company, Richland, Washington:

\subsection{APPENDICES}
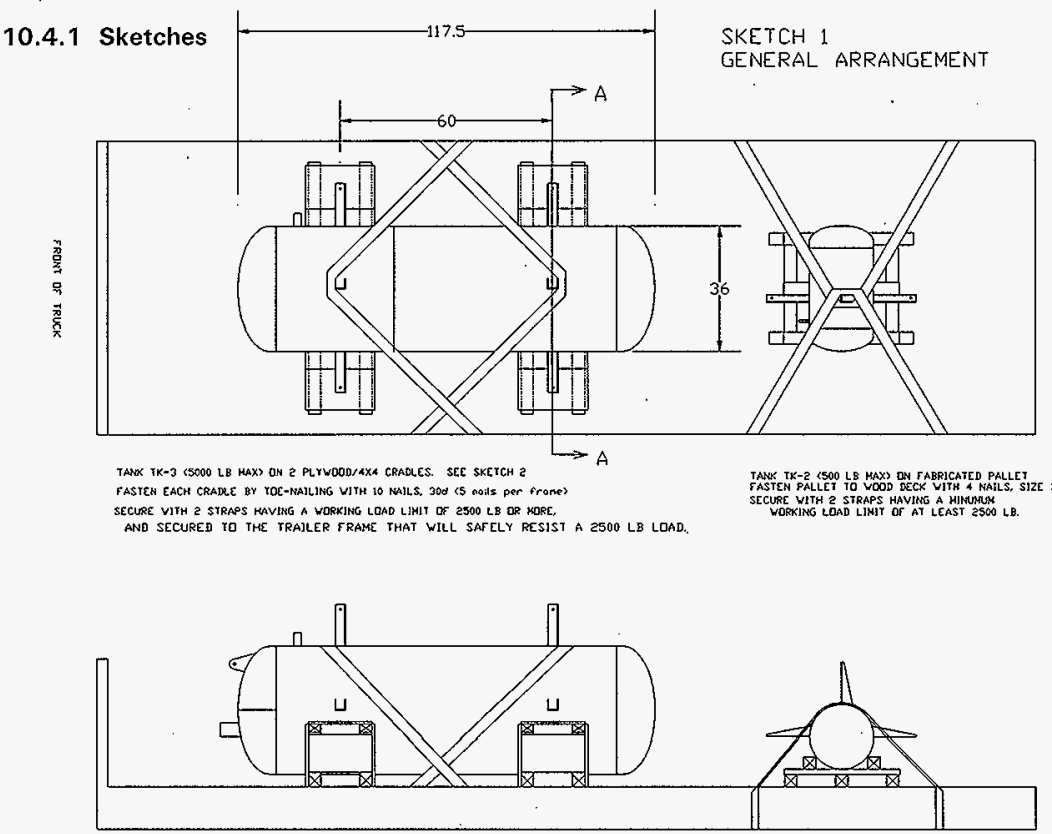

B-15 
HNF-2072, Rev. O
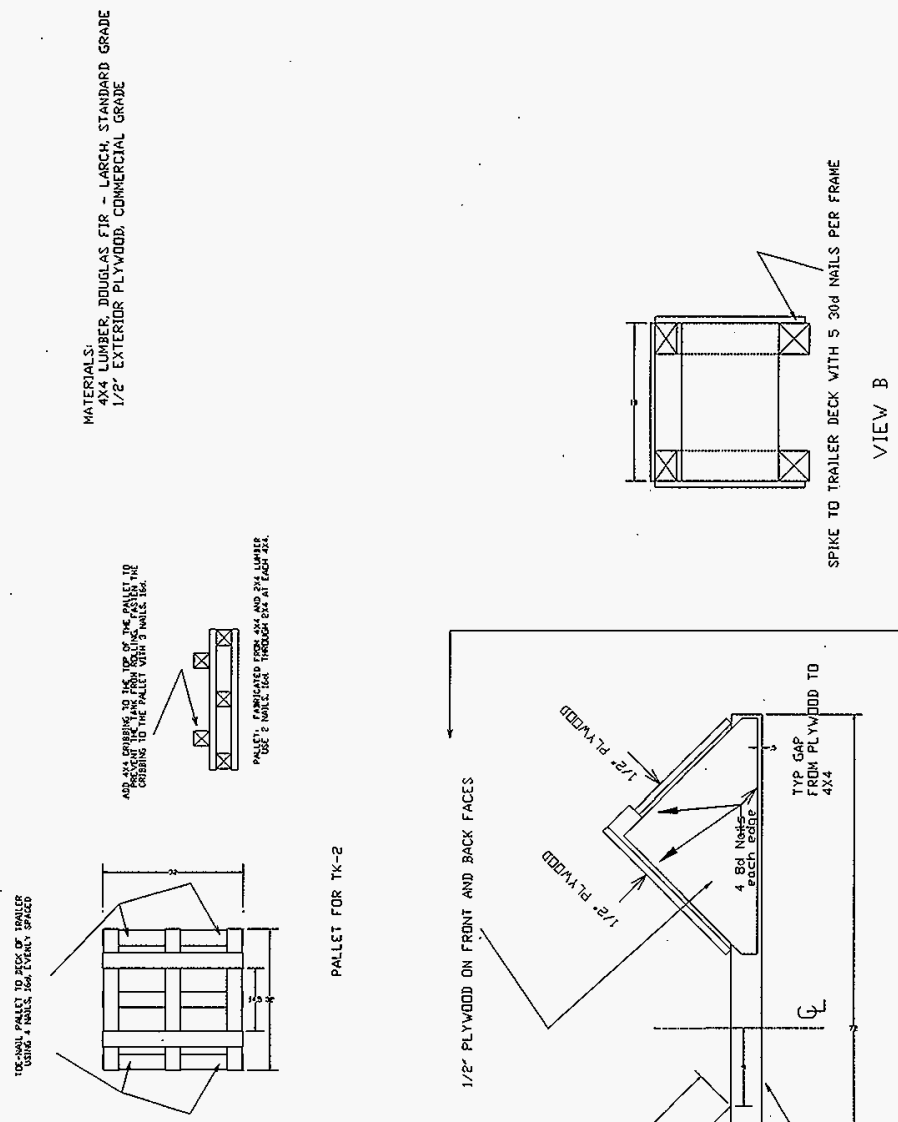

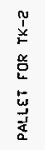

SKETCH 2

TIEDOWN DETAILS

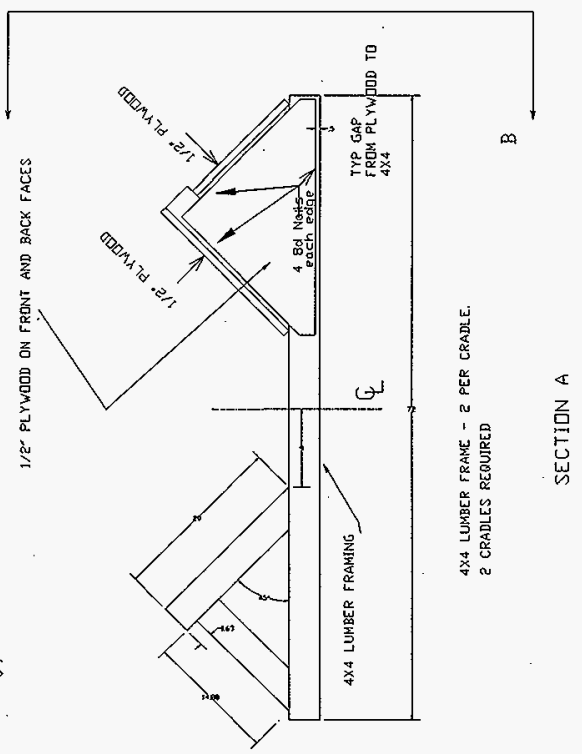


HNF-2072, Rev. O

\subsubsection{Calculations}

\section{ENGINEERING SAFETY EVALUATION}

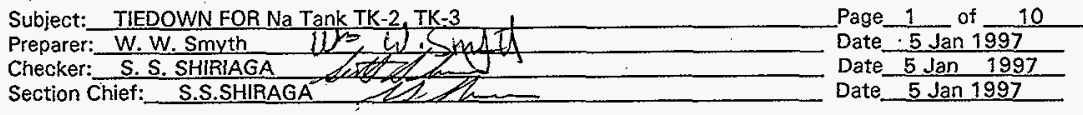

\subsection{OBJECTIVE}

Present a method for sodium tanks TK-2 and TK-3 to be secured to a trailer to meet the requirements of 49 CFR 393.

\subsection{REFERENCES}

UBC, 1988, Uniform Building Code, 1988 edition, International Conference of Building Officials, Whittier, California. 49 CFR 393, 1996, "Parts and Accessories Necessary for Safe Operation," Code of Federal Regulations, as amended. UBC Standards, 1988, Uniform Building Code Standards, 1988 edition, International Conference of Building Officials, Whittier, California.

AISC, 1980, Manual of Steel Construction, 8th edition, American Institute of Steel Construction, Chicago Ilinois, 1980

\subsection{ASSUMPTIONS, RESULTS, AND CONCLUSIONS}

It is conservatively assumed that both tanks are filled to their design capacity with sodium, but have piping, insulation and heaters removed so they appear as on their reference drawings.

The weight and center of mass for TK-3 are calculated since the drawing does not show the center of mass location. The calculated total mass is less than that on the drawing, so the tiedown calculation uses a mass slightly larger than that on the drawing. The mass and center of mass location of the smaller TK-2 are taken from the reference.

The tiedown system presented in this chapter is adequate to restrain tanks TK-2 and TK-3 against the forces required for securing hazardous materials by 49 CFR 393 when the tiedown is built to the sketches in appendix 8.4.1, fastened to the trailer deck, and when the tank is secured with straps. 
HNF-2072, Rev. 0

(a)

\section{ENGINEERING SAFETY EVALUATION}

Subject: TIEDOWN FOR Na Tank TK-2, TK-3

Preparer: W. W. Smyth

Checker: S. S. SHIRIAGA I,ES

Page. 2 of 10

Section Chief: S.S.SHIRAGA

Date 5 Jan 1997

Date 5 Jan 1997

Date 5 Jan 1997

\subsection{EVALUATION}

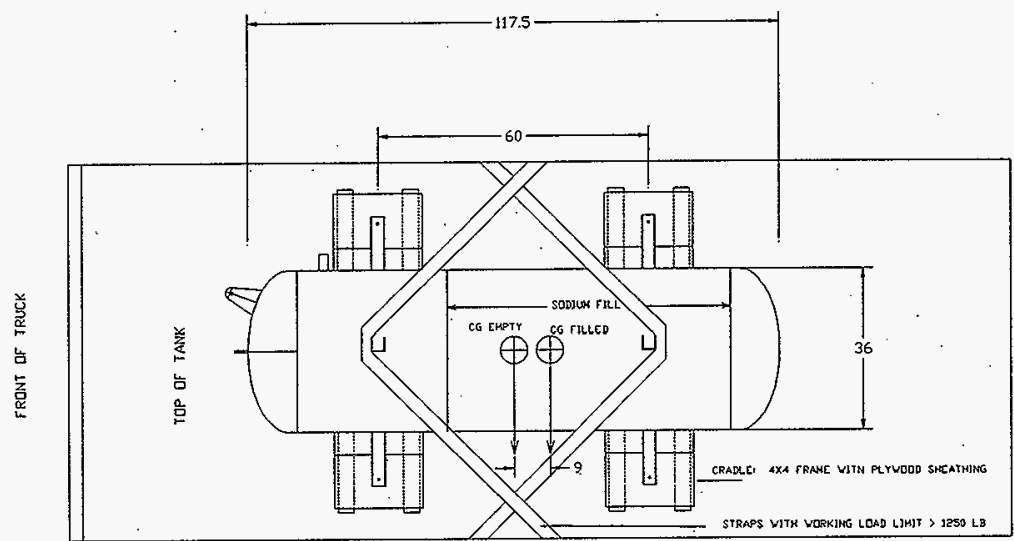

Plan view, tank TK-3 on trailer.

Tiedown method for TK-3: fasten 2 wood cradles to a wood trailer deck with nails to prevent lateral motion. As shown in the sketches in section 8.4.1, each cradle consists of two $4 \times 4$ wood frames with plywood sheathing. Each cradle is secured to the deck with $1030 \mathrm{~d}$ spikes, using 5 nails per frame, evenly spaced in the horizontal frame member. Two straps over the tank and secured to the side of the trailer provide longitudinal and vertical restraint. 
HNF-2072, Rev. 0

ख)

\section{ENGINEERING SAFETY EVALUATION}

Subject:_TIEDOWN FOR Na Tank TK-2, TK-3

Find $\mathrm{cg}$ for $\mathrm{tk}-3$ since it is not provided on the drawing:

$$
\rho_{\text {steel }}:=500 \cdot \frac{\mathrm{lb}}{\mathrm{ft}^{3}} \quad \mathrm{Sp} \cdot \mathrm{G}=.971 \quad \rho_{\mathrm{Na}}:=.971 \cdot 62.4 \cdot \frac{\mathrm{b}}{\mathrm{ft}^{3}}
$$

shell thick

$$
t:=.5 \cdot \text { in }
$$

outer diam

$D_{0}:=36 \cdot$ in

head ht $h:=10.75 \cdot$ in

$$
\text { cylinder len } L:=117.5 \cdot \text { in }-2 . \quad L=96 \cdot \text { in }
$$

fill height

$f:=73.5 \cdot$ in

steel cylinder weight: $\quad w_{1}:=\pi \cdot\left[\left(\frac{D_{0}}{2}\right)^{2}-\left(\frac{D_{0}}{2}-t\right)^{2}\right] \cdot L \cdot \rho_{\text {steel }}$

2 steel heads: $\quad W_{2}:=\frac{4}{3} \cdot \pi \cdot \rho_{\text {steel }}\left[\left(\frac{D_{0}}{2}\right)^{2} \cdot h-\left(\frac{D_{0}}{2}-t\right)^{2} \cdot(h-t)\right]$

$W_{\text {tank }}:=W_{1}+W_{2} \quad W_{\text {tank }}=1966 \cdot \mathrm{lb} \cdot$ ignoring the brackets and pipes

Assume the tank contains sodium up to its fill line

$$
\begin{array}{ll}
v_{1}:=\pi \cdot\left(\frac{D_{0}}{2}-t\right)^{2} \cdot(f-h) & v_{1}=261.35 \cdot \mathrm{gal} \\
v_{2}:=\frac{4}{6} \cdot \pi \cdot\left[\left[\left(\frac{D_{0}}{2}-t\right)^{2} \cdot(h-t)\right]\right] & v_{2}=28.46 \cdot \mathrm{gal} \\
& v_{1}+V_{2}=290 \cdot \mathrm{gal}
\end{array}
$$

cylinder sodium weight $W_{3}:=V_{1} \cdot \rho_{N}$

$$
\text { head sodium weight } \quad W_{4}:=\rho_{N a} \cdot V_{2}
$$

$$
W_{\mathrm{Na}}:=W_{3}+W_{4} \quad W_{\mathrm{Na}}=2347 \cdot \mathrm{b}
$$


HNF-2072, Rev. 0

(a)

\section{ENGINEERING SAFETY EVALUATION}

Subject: TIEDOWN FOR Na Tank TK-2, TK-3

Preparer: W. W. Smyth

ans

Page 4 . f 10

Checker: S. S. SHIRIAGA

Date 5 Jan 1997

Section Chief: S.S.SHIRAGA

Date 5 Jan 1997

Date 5 Jan 1997

$$
W_{\text {tot }}:=W_{\mathrm{Na}}+W_{\tan } \quad W_{\text {tot }}=4313 \cdot 1 \mathrm{~b}
$$

On the drawing, Na weight is $2105 \mathrm{lb}$, total weight is $4385 \mathrm{lb}$, and the sodium volume is 300 gal.

cg of sodium, measured from outside of bottom head:

$$
Z_{\mathrm{Na}}:=\frac{W_{3} \cdot\left(\frac{\mathrm{f}-\mathrm{h}}{2}+h\right)+W_{4} \cdot f \cdot \frac{5}{8}}{W_{3}+W_{4}} \quad Z_{\mathrm{Na}}=42.5 \cdot \mathrm{in}
$$

Find a general expression for the center of mass for the lower half of an ellipsoid with radii $r, r$, and $h$ :

$$
x^{2}+y^{2}=r^{2} \cdot\left[1-\left(\frac{z}{h}\right)^{2}\right]\left(\frac{x}{r}\right)^{2}+\left(\frac{y}{r}\right)^{2}+\left(\frac{z}{h}\right)^{2}=1
$$

Area of circle at arbitrary value of $z: \pi \cdot R(z)^{2}=\pi \cdot\left(x^{2}+y^{2}\right)$

Volume: $\operatorname{VOL}(r, h):=\int_{0}^{h} \pi \cdot r^{2}:\left(1-\frac{z^{2}}{h^{2}}\right) d \quad \operatorname{VOL}(r, h):=\frac{2}{3} \cdot \pi \cdot r^{2}$.

First moment with respect to $x y$ plane: $\quad M Z(r, h):=\int_{0}^{h} z \cdot \pi \cdot r^{2} \cdot\left(1-\frac{z^{2}}{h^{2}}\right) d$

$$
\begin{gathered}
M Z(r, h):=\frac{1}{4} \cdot \pi \cdot r^{2} \cdot h^{2} \\
C G(r, h):=\frac{M Z(r, h)}{V O L(r, h)} \quad C G(r, h):=\frac{3}{8} . \\
Z_{\text {total }}:=\frac{\left(\frac{L}{2}+h\right) \cdot W_{\text {tank }}+W_{N a} \cdot Z_{N a}}{W_{\text {tank }}+W_{N a}} \quad Z_{\text {total }}=49.91 \cdot \text { in }
\end{gathered}
$$


HNF-2072, Rev. 0

iiv

ENGINEERING SAFETY EVALUATION

Subject: TIEDOWN FOR Na Tank TK-2, TK-3

Preparer: W.W. Smyth

Checker: S. S. SHIRIAGA

h厂s

Section Chief:

S.S.SHIRAGA

Page 5 of 10

Date 5 Jan 1997

Date 5 Jan 1997

Date 5 Jan 1997

distance from tank's geometric center to center of gravity of filled tank:

$$
d:=\frac{L}{2}+h-Z_{\text {tota }} \quad d=8.8 \cdot \text { in }
$$

For this analysis, use a tank weight of $5000 \mathrm{lb}$, with $\mathrm{cg} 9$ in from center of tank. The distance between wood cradles is $60 \mathrm{in}$. Find the maximum weight and horizontal forces due to $1 / 2 \mathrm{~g}$ lateral acceleration on the cradle under the heavy end of the tank. Treat the tank as a simple beam on 2 supports.

$$
\begin{aligned}
& \text { Weight }:=5000 \cdot 1 \mathrm{~b} \cdot \frac{\frac{60}{2} \cdot \mathrm{in}+9 \cdot \text { in }}{60 \cdot \mathrm{in}} \\
& \text { Weight }=3250 \cdot 1 \mathrm{~b} \\
& \text { Force }:=.5 \cdot \text { Weigh Force }=1625 \cdot \mathrm{lb}
\end{aligned}
$$

Design the cradles to support this force applied laterally through the center of the tank and 1.5 times the force applied vertically.

Lateral load:

$\mathrm{a}:=45 \cdot \mathrm{deg}$

$$
\text { Normal Force: } \quad \mathrm{N}:=\frac{\text { Force }}{\sin (\mathrm{a})}
$$

$N=2298 \cdot 1 \mathrm{~b}$

Vertical reaction:

$V:=$ Weight $-N \cdot \cos (a) V=1625 \cdot \mathrm{lb}$

Since $V>0$, the tank will not roll or move laterally unless the cradle moves. Movement will be prevented by fastening the $4 \times 4$ beam to the

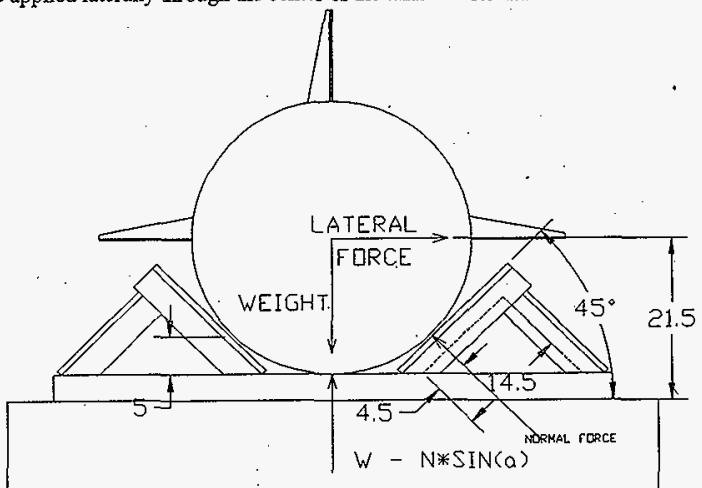

trailer deck. To design the fastening system, use UBC Standards, 1988: Douglas Fir-Larch is listed as group II, with a specific gravity of 0.51 in table 25-17-I. Use the UBC 1988100 increase in allowable load for short 
HNF-2072, Rev. O

ENGINEERING SAFETY EVALUATION

Subject: TIEDOWN FOR Na Tank TK-2, TK-3

Preparer: W.W. Smyth W W

Page 6 of 10

Checker: S. S. SHIRIAGA

Date 5 Jan 1997

Section Chief:

S.S.SHIRAGA

Date 5 Jan 1997

Date $\quad 5$ Jan 1997

durations. Assume the wood deck is at least 1.5 in thick. A $30 \mathrm{~d}$ common spike provides $94 \mathrm{lb}$ lateral resistance when it penetrates 11 diameters (1.63 in) through a group II species wood. Reduce the resistance for 1.5 in penetration and increase it for short duration. Calculate the number of nails needed to prevent the cradle from moving:

$$
\mathrm{N}_{\mathrm{n}}:=\frac{\text { Force }}{\left(\frac{1.5}{1.63}\right) \cdot 2 \cdot 94 \cdot \mathrm{lb}} \quad \mathrm{N}_{\mathrm{n}}=9.393
$$

Toe-nail the $4 \times 4$ beams with a total of 10 nails, using $30 \mathrm{~d}$ common nails. Each $4 \times 4$ horizontal frame member should have 5 evenly spaced nails.

Compliance with the DOT tiedown requirements for vertical forces of 49 CFR 393.100 is achieved if the two straps have a working load limit of the weight $/ 2$, or $2500 \mathrm{lb}$. Calculate the force in the straps assuming the strap makes an angle of 45 degrees in the horizontal and the vertical plane:

$$
\begin{aligned}
& I_{x}:=1 I_{y}:=1 \text { projections of strap length in lateral and longitudunal directions } \\
& I_{h}:=\sqrt{2} \text { horizontal projection of strap length } \\
& I_{V}:=1
\end{aligned}
$$

Vertical restraint (4 legs active): Len := $\sqrt{1 h^{2}+I_{v}{ }^{2}}$

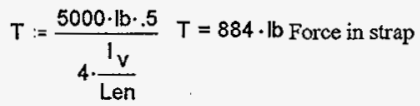

Longitudinal restraint ( 2 legs active):

$$
T:=\frac{5000 \cdot \mathrm{lb} \cdot .5}{2 \cdot \frac{\mathrm{I}_{\mathrm{x}}}{\operatorname{Len}}} \mathrm{T}=2500 \cdot \mathrm{lb} .
$$

Therefore, the straps need a working load limit of $2500 \mathrm{Ib}$. 
HNF-2072, Rev. 0

ENGINEERING SAFETY EVALUATION

Subject: TIEDOWN FOR Na Tank TK-2, TK-3

Preparer: W.W. Smyth WFs

Page 7 of 10

Checker: S. S. SHIRIAGA

S.S.SHIRAGA

Date 5 Jan 1997

Date 5 Jan 1997

Section Chief:

Date 5 Jan 1997

Find the stress in the $1 / 4$ " fillet weld connecting the bracket to the tank. The force applied to the joint is $1 / 2$ of the tank weight since only one strap is active. Weld shear stress is:

$$
\begin{aligned}
& f_{v}:=\frac{.5 \cdot 5000 \cdot \mathrm{b}}{.707 \cdot 2 \cdot 25 \cdot \mathrm{in} \cdot 3 \cdot \mathrm{in}} \quad f_{v}=2357 \cdot \frac{\mathrm{lb}}{\mathrm{in}^{2}} \\
& F_{y}:=30000 \cdot \frac{\mathrm{lb}}{\mathrm{in}^{2}}
\end{aligned}
$$

Either type 304 or 316 was used for the tanks. Both have a yield stress of 30,000 psi. AISC fillet weld criteria for Working Stress Design (AISC, 1980) is:

$$
\begin{aligned}
& F_{v}:=.4 \cdot F \\
& F_{v}=12000 \cdot \frac{\mathrm{lb}}{\mathrm{in}^{2}}
\end{aligned}
$$

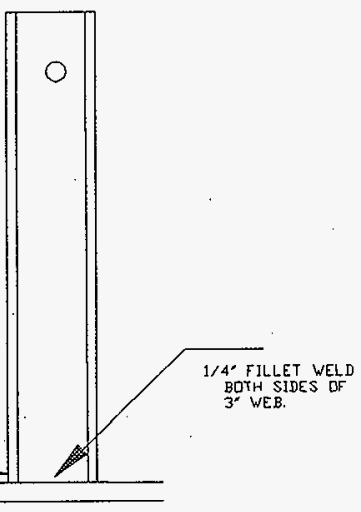

There is a large margin between the shear stress in the weld and the allowable, so the strut may be used to secure the load as long as the strap is against the tank and is not bending the strap.

Check the beam stress in the $4 \times 4$ beam in contact with the tank. UBC 1988 allows a bending stress of $625 \mathrm{psi}$ in "standard grade" Douglass Fir - Larch, and a shear stress of 95 psi (table 25-A-1). For impact loads, these allowable stress are doubled. Use the dimensions above to find the beam shear and bending moment, assuming simple beam support conditions. The loads are shared equally between 2 beams, and are applied 4.5 " from the lower end of the $14.5^{\text {"beams. }}$

$$
V:=\frac{N}{2} \cdot \frac{14.5-4.5}{14.5}
$$

$$
\text { Maximum shear }=\text { left beam reaction }
$$


HNF-2072, Rev. 0

(I)

ENGINEERING SAFETY EVALUATION

Subject: TIEDOWN FOR Na Tank TK-2, TK-3

Preparer: W. W. Smyth

Page 8 of 10

Checker: S. S. SHIRIAGA

Date 5 Jan 1997

Section Chief: S.S.SHIRAGA

Date 5 Jan 1997

Date 5 Jan 1997

$$
\begin{aligned}
& \text { dimensions for nominal } 4 \times 4 \text { size } \\
& b:=3.5 \cdot \text { in } \\
& d:=3.5 \text {-in } \\
& f_{v}:=\frac{3 \cdot v}{2 \cdot b \cdot d} \quad f_{v}=97 \cdot \frac{1 b}{i n^{2}} \\
& \text { calculated shear stress shear margin: } \frac{2 \cdot 95 \cdot \frac{\mathrm{lb}}{\mathrm{in}^{2}}}{f_{v}}-1=0.96 \\
& M:=V \cdot 4.5 \cdot \text { in } \quad S:=\frac{1}{6} \cdot b \cdot d^{2} \quad \text { moment and section modulus } \\
& f_{b}:=\frac{M}{S} f_{b}=499 \cdot \frac{\mathrm{lb}}{\mathrm{in}^{2}} \quad \text { bending stress margin: } \quad \frac{2 \cdot 625 \cdot \frac{\mathrm{lb}}{\mathrm{in}^{2}}}{\mathrm{f}_{\mathrm{b}}}-1=1.5
\end{aligned}
$$

The lateral force is transmitted to the $4 \times 4$ floor beam through plywood panels nailed to the $4 \times 4$ floor and diagonals. Calculate the shear in each plywood panels: $1 / 2$ " plywood is nailed to the front and back surfaces of each assembly, so 4 panels carry the shear. UBC 1988 Standards, table 25-9-H gives an effective shear thickness of 0.425 in for $1 / 2$ in sanded plywood for through-thickness shear.

The bottom of the panel is 27 " long, so:

$$
f_{v}:=\frac{.25 \cdot \text { Force }}{(.425 \cdot \text { in } \cdot 27 \cdot \text { in })} f_{v}=35 \cdot \frac{\mathrm{lb}}{\mathrm{in}^{2}}
$$

UBC 1988 allows a shear of 44 psi for normal-duration shear in the plane of the plies. Double this for impact loading to calculate a shear margin:

$$
\frac{2 \cdot 44 \cdot \frac{\mathrm{lb}}{\mathrm{in}^{2}}}{f_{v}}-1=1.5
$$

Any grade of $1 / 2$ "plywood is adequate to transmit the lateral load as shear stress to the bottom $4 \times 4$ chord. 
HNF-2072, Rev. 0

(2)

\section{ENGINEERING SAFETY EVALUATION}

Subject: TIEDOWN FOR Na Tank TK-2, TK-3

Preparer: W. W. Smyth

Checker: S. S. SHIRIAGA

Page 9 of 10

Date 5 Jan $\$ 997$

Section Chief: S.S.SHIRAGA

Date 5 Jan 1997

Date $5 \operatorname{Jan} 1997$

Find the number of nails needed at bottom of plywood based on UBC standards for allowable diaphragmin loading.

Diaphragm shear (lb/ft): $\quad .25 \cdot \frac{\text { Force }}{27 \cdot \mathrm{in}}=181 \cdot \frac{\mathrm{lb}}{\mathrm{ft}}$

UBC table 25-J-2 shows an allowable diaphram shear of $270 \mathrm{lb} / \mathrm{ft}$ with an edge nailing schedule of $8 \mathrm{~d}$ nails @ $6^{H}$ spacing in $2^{\prime \prime}$ nominal lumber. Use minimum of 4 nails (8d) per side.

TANK TK-2 REF DWG H-2-38805 MAX GROSS WT 500 LBF, FILLED WITH SOLID SODIUM
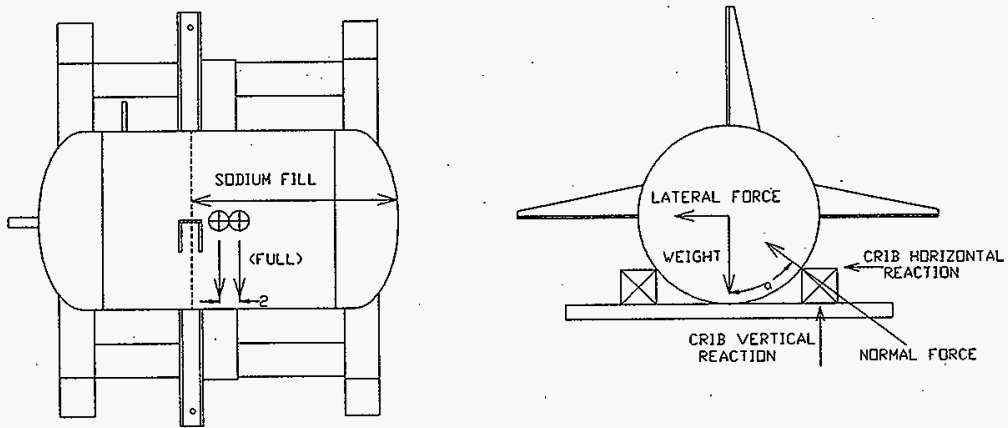

PLAN VIEW: TK-Z IN PALLET 
HNF-2072, Rev. O

(iii)

\section{ENGINEERING SAFETY EVALUATION}

Subject: TIEDOWN FOR Na Tank TK-2, TK-3

Preparer: W.W. Smyth G/

Checker: S. S. SHIRIAGA

Section Chief:

S.S.SHIRAGA

Page 10 of 10

Date 5 Jan $19 \overline{97}$

Date 5 Jan 1997

Date 5 Jan 1997

Due to the small size of the tank, a pallet is needed to raise it so straps can have a good lead. It will be carried on the same trailer with TK-3, but with the cylindrical axis across the width of the trailer. This requires a pallet with cribbing added to it to restrain the tank against braking and acceleration loads. $4 \times 4$ lumber cribbing nailed to the top of the pallet will be added. Find the maximum load on the $4 \times 4$ cribbing:

$O D:=18 \cdot$ in tank diameter

$h:=3.5 \cdot$ in Crib height

find the angle that the crib normal force makes with the vertical:

$$
\begin{aligned}
& \frac{O D}{2} \cdot(1-\cos (a))= \\
& a:=\operatorname{acos}\left[\frac{(O D-2 \cdot h)}{O D}\right] a=52.33 \cdot \mathrm{deg}
\end{aligned}
$$

Use 3 fasteners to secure the lateral force-resisting crib to a pallet, and design the fasteners so 2 can withstand the lateral load - this lets us neglect the eccentricity of the loading on the crib.

Weight $:=500 \cdot 1 \mathrm{~b}$

Lateral force: Force $:=.5 \cdot$ Weigh Force $=250 \cdot \mathrm{lb}$

Normal Force: $\mathrm{N}:=\frac{\text { Force }}{\sin (\mathrm{a})} \mathrm{N}=316 \cdot \mathrm{lb}$

Vertical reaction: $V:=$ Weight $-N \cdot \cos (a) V=307 \cdot \mathrm{lb}$

Since $V>0$, the tank is stable.

Each fastener securing the $4 \times 4$ crib to the pallet must resist $1 / 2$ of the lateral force, or

$\frac{\text { Force }}{2}=125 \cdot \mathrm{lb}$

Either toe-nail the $4 \times 4$ to the top of the pallet with $316 \mathrm{~d}$ nails $(82 \mathrm{lb}$ lateral load allowable for normal load duration (UBC 1988, TABLE 25-G) or lag screw from the bottom of the pallet. The pallet must be made from $2 \times 4$ and $4 \times 4$ lumber for the fasteners to be effective. 


\section{DISTRIBUTION SHEET}

\begin{tabular}{|c|c|c|c|c|c|c|}
\hline \multirow{2}{*}{$\begin{array}{l}\text { To } \\
\text { Distribution }\end{array}$} & \multirow{2}{*}{\multicolumn{4}{|c|}{$\begin{array}{l}\text { From } \\
\text { Packaging Engineering }\end{array}$}} & \multicolumn{2}{|l|}{ Page 1 of 1} \\
\hline & & & & & \multicolumn{2}{|c|}{ Date Jan. 21, 1998} \\
\hline \multicolumn{5}{|l|}{ Project Title/Work Order } & \multicolumn{2}{|c|}{ EDT No. 621883} \\
\hline \multicolumn{5}{|c|}{$\begin{array}{l}\text { Safety Evaluation for Packaging (Onsite) } 221 \text { T Sodium Tanks } \\
\text { (HNF-2072, Rev. O) }\end{array}$} & ECN No. $\quad \mathrm{N} / \mathrm{t}$ & \\
\hline Name & & MSIN & $\begin{array}{c}\text { Text } \\
\text { With All } \\
\text { Attach. }\end{array}$ & Text Only & $\begin{array}{l}\text { Attach./ } \\
\text { Appendix } \\
\text { Only }\end{array}$ & $\begin{array}{l}\text { EDT/ECN } \\
\text { Only }\end{array}$ \\
\hline $\begin{array}{l}\text { W. F. Brehm, Jr. } \\
\text { R. L. Clawson } \\
\text { J. A. Demiter } \\
\text { J. G. Field } \\
\text { C. R. Hoover } \\
\text { W. A. McCormick } \\
\text { T. Romano }\end{array}$ & & $\begin{array}{l}N 2-56 \\
H 1-14 \\
B 4-51 \\
H 1-15 \\
H 1-15 \\
H 1-15 \\
\text { G1-15 }\end{array}$ & $\begin{array}{l}x \\
X \\
x \\
x \\
x \\
x \\
x \\
x\end{array}$ & & & \\
\hline HNF-207.2 Fil.e & & $\mathrm{HI}-15$ & $x$ & . & & \\
\hline Central Files & & B $7-07$ & $x$ & & & \\
\hline
\end{tabular}

